\title{
The IMPlementation OF Giving TASK METHOD TO IMPROVE STUdENTS' ACHIEVEMENT
}

\author{
Yopi Nisa Febianti \\ Universitas Swadaya Gunung Jati, Cirebon, Indonesia \\ E-mail: taniabekker@yahoo.com
}

\begin{abstract}
There are some learning methods used by educators that aim to motivate learners to be diligent and enjoy learning. Learners who have high motivation to learn will play an active role, critical thinking, social interaction, creativity, and focus while learning. One of the methods that can encourage the creativity of learners in learning to improve creativity and knowledge for achieving satisfying learning outcomes is the assignment method. This research aims to analyze whether or not the giving-task method can improve students' achievement in the letter of credit material. The method used in this research is class action research that consists of two cycles, starting from planning, giving treatment, and reflection. To collect the data, the writer uses a subjective test. The data source is the first-grade students (I.B) of the Economic Education Department Faculty of Teachers' Training And Educational Sciences UGJ. The result of this research shows that giving task method can improve students' achievement. It is shown from the satisfying score got by students. In the first cycle, the average score is 45.29 while in the second cycle, it is 89.00 . This research concludes that the giving-task method can help students comprehending the letter of credit concept and it develops the students' responsibilities individually or in group work and their creativities during the learning process.
\end{abstract}

Keywords: Learning Method; Giving-Task Method; Students’ Achievement

\section{INTRODUCTION}

For an educator, the only way to build a qualified successor is to provide good and satisfying education in school. Education that is provided through learning activities should be able to develop the learners' quality and social quality. The learners' quality is derived from insights and knowledge, both self-gained and from others (family, school, and community), while the social quality is derived from the social process of learners in interacting with others, both in the family, school, and community.

Education is done through impressive teaching that will produce the desired learning. That is an aspect that should be emphasized to educators (teachers/lecturers) that good learning is learning that takes place with the involvement of students actively. By activating learners in learning will improve students' understanding of the materials taught, so that the success of learners in learning can be achieved, especially in improving learning outcomes. Learning outcomes include cognitive, affective, and psychomotor abilities (Suprijono, 2011).

According to Nawawi (Istiatutik, 2017) based on its objectives, learning outcomes are divided into three types, namely: (a) Learning outcomes in the form of ability skills or abilities in doing or doing a task, including the skills to use tool; (b) Learning outcomes in the form of the ability to master knowledge about what is done; and (c) Learning outcomes in the form of changes in attitudes and behavior. Learning as a process has several separate elements which include learning goals to be achieved, motivation, obstacles, stimuli from the environment, perceptions, and responses from students (Sitompul, 2018).

The success of an educator in teaching is influenced by the creativity of the educator in creating an atmosphere of learning that is memorable and fun. Rowntree (Anshori, Wagimin, \& Ninghardjanti, 2016) suggested that four indicators can be used to determine the success of a learning process, namely: (a) Able to improve student learning outcomes; (b) Able to motivate students to study further; (c) Able to improve students' memory or retention of content/subject matter; and (d) Able to make students apply the knowledge and skills learned. To optimize its creativity, an educator can create an innovative learning method, which can encourage the learner and their creativity in the learning process. Arikunto (Khumaidi, 2018) said that learning is a process that contains a series of actions by teachers and students based on reciprocal relationships that take place in educative situations to achieve certain goals. The teacher is 
the creator of the learning process, which means a teacher must be able to develop a free classroom atmosphere for students to study what is interesting and able to express ideas and creativity within the limits of the established norms consistently.

There are some learning methods used by educators that aim to motivate learners to be diligent and enjoy learning. The important thing in the method is that each learning method used is related to the learning objectives to be achieved. The purpose of educating children to be able to solve problems in learning requires another method if the aim is to gather information (Sagala, 2013). Learners who have high motivation to learn will play an active role, critical thinking, social interaction, creativity, and focus while learning. One of the methods that can encourage the creativity of learners in learning to improve creativity and knowledge for achieving satisfying learning outcomes is the assignment method.

The assignment method is a method that is oriented on constructivist philosophy. The assignment method is a way of presenting lessons by assigning students to learn something which then must be accounted for (Permatasari, Mulyani, \& Nurhayati, 2014). The assignment method is a method that essentially instructs students to carry out learning activities (work), both useful for themselves and in the process of deepening and expanding the knowledge and understanding of the field of study they are learning (Widhiantari, 2012).

The assignment method is one of the learning strategies used by an educator to encourage the creativity of learners in completing tasks assigned so that the task can be given independently or in groups. The assignment is related to the subject matter discussed in class.

Using the tasks method, learners can easily understand the learning materials provided. They will continue to search, find, and accomplish the task in various ways that enable them to go, such as by reading books, searching the internet, and conducting investigations in the family, school, or community, so that the results of those searches can be more easily absorbed in the memories of learners.

This method can also train the sense of learners' responsibility in doing the task independently, not assisted by others and not the result of imitating the work of others, it's their results. It will provide good benefits for learners in adding insight and knowledge. The task work independently will be more satisfying, because all the learning processes to complete the task is experienced by learners. A more satisfying result is if the workman's task is rewarded with a perfect score. In explaining the material to the learners, this method will be effective because the material will be comprehended by learners so they can achieve the learning objective well.

\section{Methodology}

In this research, the research method used is action research class (PTK). This study is designed to solve a problem, tested in real situations by looking at flaws and strengths, and making changes that serve as improvements.
Action research class has its character when compared with other studies in general. Some of these characters are as follows Suyadi (2013): (a) The teacher feels that there are urgent problems to be immediately resolved in his class; (b) self-reflection; (c) Action research class is carried out in the class so that the focus of attention is the learning process between the teacher and students through interaction; and (d) Action research class aims to improve the learning process continuously.

This remedial action is carried out by carrying out actions to find answers to issues raised from daily activities in the classroom. Action research is nothing but a research method, in which a group of people who are also researchers in organizing a condition, can intensively study the experience and make their experience accessible to others (Sukardi, 2013). The subject in this research is the second-grade student (I.B) Economic Education FKIP Unswagati which amounted to 21 students. This research took place at Unswagati Cirebon. The study was conducted using procedures following the Classroom Action Research flow. The steps of research conducted, are named as follows:

a. Action Planning

When the researcher gets into trouble in learning the Letter of Credit materials, the researcher plans an action to overcome the problems faced. The first step is designing the strategy to be taken, by preparing the Lesson Plan, learning media, evaluation tools, and research instruments. In this stage, the researcher takes one of the problem-solving alternatives by planning the lesson using the assignment method.

b. Implementation Action

The implementation phase of the action is the implementation of all the planning that has been designed in the action planning stage. In this stage, the researcher conducts the learning process which is carried out following the lesson plan that has been designed.

c. Analysis and Reflection Action

After taking action, the next step is analyzing the activities that have been implemented during the learning process as a reflection activity. In this stage, the researcher analyzes the learning process that has been implemented through student learning outcomes and evaluates these activities for improvement in the next stage.

The technique used in collecting data for this research is the subjective test. The subjective test used is an essay in Cycle 1 and Cycle 2. The purpose of the test is to measure the extent of student learning outcomes after following the learning process using the method of assignment. Data analysis is done after the learning process in the class, that is analyzing student learning outcomes for Action 1 and Action 2, uses Microsoft Office Excel 2010 and AnatesV4 program. Furthermore, in this study, the action is called a cycle. 


\section{RESULTS AND DISCUSSION}

This classroom action research is divided into two parts, namely Cycle 1 and Cycle 2. Cycle 1 and Cycle 2 are the learning outcomes after using the assignment method.

\section{A. Cycle 1}

The implementation of Cycle 1 is the following lesson plan that has been made. In this stage, the teaching and learning activities are started with preparing classes such as hygiene cleaning and inspection, so the class is comfortable to use in the learning process. After the class is considered comfortable to start learning, the lecturer explains the learning objectives to the students. The exposure of learning objectives is done to provide an idea to the students about the learning process that will be done. After that, to refresh students' memories, the lecturer discusses the concept of letters of credit globally.

In the next stage, the lecturer divides the students into 7 groups, each group consists of 3 students. After that, the lecturer gives the task, in the form of a letter of credit material that should be sought to all students. Each member of the group is assigned a different task. For the work, the task is given time for 30 minutes. Each student is free to search the subject matter of the letter of credit, either from books relating to the material, the internet, or discuss with other group members who have the same task. Each student is fully responsible for individual and group duties. After the specified time has ended, the lecturer asks each group to present their assignments in front of the class. Students who have answers to different tasks with other groups can express ideas/opinions. After that, the lecturer discusses the material letter of credit in detail following the time available, with the help of available learning media, namely projectors, LCDs, netbooks, and others. At this stage, all the explanations given by the lecturer should be well observed by the students. With high learning motivation, all the explanations given can be easily understood and absorbed in students' memories, or vice versa, so that their insight and knowledge about the matter of letter of credit increases or not.

In closing activities, the lecturer provides evaluation questions to measure students' learning outcomes after the learning process. Then, the lecturer gives homework where the students have to study the lecture material for the next meeting, still about letters of credit material that must be done independently by the students.

As a result of the observation during the learning process towards the students, it can be seen that from the whole students who attended during the learning, only some students were active and interacted in doing the assigned task, both individual and group. Some students look bored, saturated, drowsy, confused, and indifferent during the learning process, they rely on one group of friends in finding answers for the task or imitate the results of the task from their friend in another group with the same task when the lecture material inference process is done the students tend to be indifferent. Nevertheless, teaching and learning activities run smoothly, but the liveliness and responsibility of students in learning are still less than satisfactory. The value of learning results obtained by students after taking the evaluation test from Cycle 1 can be seen in Table I.

TABLE I

RESults OF STUdent LEARNing EVALUATION CYCle 1

\begin{tabular}{clc}
\hline No. & Name of Students & Score \\
\hline 1 & R1 & 48 \\
2 & R2 & 50 \\
3 & R3 & 48 \\
4 & R4 & 42 \\
5 & R5 & 37 \\
6 & R6 & 31 \\
7 & R7 & 40 \\
8 & R8 & 40 \\
9 & R9 & 50 \\
10 & R10 & 37 \\
11 & R11 & 34 \\
12 & R12 & 54 \\
13 & R13 & 34 \\
14 & R14 & 37 \\
15 & R15 & 34 \\
16 & R16 & 48 \\
17 & R17 & 39 \\
18 & R18 & 44 \\
19 & R19 & 34 \\
20 & R20 \\
21 & R21 & 46 \\
& Total & 39 \\
\hline & Average & $\mathbf{8 6 6}$ \\
& & $\mathbf{4 1 . 2 3 8 0 9 5 2 4}$ \\
\hline
\end{tabular}

From Table I, it is known that the average of students' learning outcomes in Cycle 1 is 41.24. Description of students' learning outcomes in Cycle 1 can be seen in Fig.1.

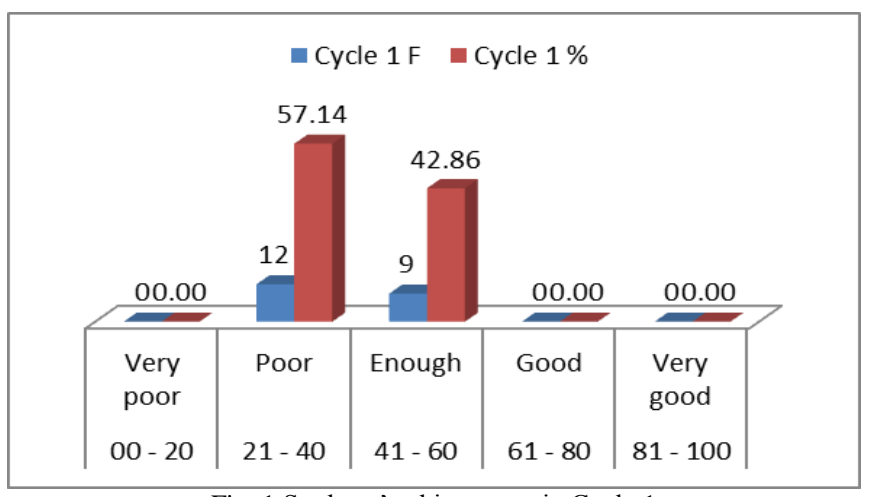

Fig. 1 Students' achievement in Cycle 1

From Fig. 1, it can be seen that the students who get the learning outcomes with the very poor category are none $(0 \%)$; Students who get the learning result with the poor category are 12 people (57.14\%); Students who get the learning outcomes with enough category are 9 people $(42.86 \%)$; Students who get good learning outcomes are none $(0 \%)$; and students who get the learning outcomes with the very good category is none $(0 \%)$. 
If we look at the results of Cycle 1, it is clear that there should be significant improvements in learning to minimize any remaining deficiencies. These deficiencies include:

1. The lecturer is still not able to conditioning students at the beginning of learning. This can be seen from that there are still students who pay less attention and respond to the lecturer's questions at the beginning of learning.

2. The lecturer is still less familiar with the students, both of who can catch quickly or not to the learning materials.

3. The lecturer still pays less attention to students who are less active in learning.

4. Students are still reluctant to ask the lecturer if they have difficulty during the learning process, also they are not confident to express their ideas/opinions.

5. Students less actively participate and have less social interaction in doing the tasks given during the learning process.

6. Students are less responsible for the task given.

Based on the findings in Cycle 1, then efforts to maintain success and improve learning in Cycle 2, the lecturer makes the following planning:

1. The lecturer prepares more conditioned students at the beginning of learning, motivates students with questions that can attract students, so that teaching and learning activities can run more calm and conducive.

2. The lecturer should be more familiar with students, whether they have a fast understanding or not on learning materials, so that the material can be easily absorbed and understood by them.

3. The lecturer should be more active or give more attention to students or groups who are more passive.

4. The lecturer should encourage students 'self-esteem with questions and give praise when students can answer correctly, and not minimize student answers if students answer incorrectly, but cultivate expectations by improving students' answers or opinions.

5. The lecturer can encourage students' sense of responsibility so that they can deliver satisfactory outcomes based on their work, providing satisfactory rewards.

6. The lecturer should be able to create a fun learning atmosphere so that student motivation remains high.

\section{B. Cycle 2}

Implementation of Cycle 2 is done following SAP that has been made. At this stage, the teaching and learning activities begin with preparing conditioned classes such as hygiene cleaning and inspection, so the class is comfortable to use in the learning process. After the class is considered comfortable to start learning, the lecturer explains the learning objectives to the students. The exposure of learning objectives is done to provide an idea to the students about the learning process that will be done. After that, to refresh the student's memory, the lecturer again discussed the concept of the letter of credit globally.

In the next stage, the lecturer divides the students into 7 groups in which each group consists of 3 students. After that, the lecturer gives the task, in the form of some material of letter of credit that should be sought to all students. Each member of the group is assigned a different task. For the work, the task is given time for 30 minutes. Each student is free to search the subject matter of the letter of credit, either from books relating to the material, the internet, or discuss with other group members who have the same task. Each student is fully responsible for individual and group duties. After the specified time has ended, the lecturer asks each group to present their assignments in front of the class. Students who have answers to different tasks with other groups can express ideas/opinions. After that, the lecturer discusses the material letter of credit in detail following the available time, with the help of available learning media, namely projectors, LCDs, netbooks, and others. At this stage, all the explanations given by the lecturer should be well observed by the students. With high learning motivation, all the explanations given can be easily understood and absorbed in students' memories, or vice versa, so that their insight and knowledge about the matter of letter of credit increases or not.

In closing activities, the lecturer provides evaluation questions to measure students' learning outcomes after the learning process. Then, the lecturer gives the housework where the student must study the lecture material for the next meeting.

In the learning done on this 2 nd cycle, it is seen that the students are actively involved and interact in the work assignment. They do the task independently and discuss it with other group members who have the same task. They are also more active in presenting tasks, as well as expressing their ideas/opinions. Student mindset is well developed, their learning motivation is high, and the learning atmosphere is conducive and fun. Nevertheless, some students are still indifferent during the learning process, they have not been motivated to study harder yet. The value of learning results obtained by students after taking the evaluation test from Cycle 2 can be seen in Table II.

From Table II, it is known that the average of students' learning outcomes in Cycle 2 is 85.33. Description of student learning outcomes in Cycle 2 can be seen in Fig. 2.

From Fig. 2, it can be seen that students who get learning outcomes with the very poor category are none $(0 \%)$; Students who get the learning result with the poor category is none $(0 \%)$; Students who obtain learning outcomes with enough category are none $(0 \%)$; Students who get good learning category are 4 persons $(19.05 \%)$; and students who get the results of the study with the very good category are 17 people $(80.95 \%)$.

From the results of the implementation and observations carried out in Cycle 2, it can be stated that learning by applying the giving task method is very good. After the implementation in Cycle 2, it can be concluded that:

1. All students have been actively involved, responsible, interacting, and their mindset developed well during the learning process. The lecturer has been able to condition the class so that learning can take place more conducive and fun. 
2. The learning achievements in cycle 2 increased comparing with cycle 1 . It can be seen from the average score of learning achievement in cycle 2 (85.33) and cycle 1 (41.24). Most of the students get scores in a very good category. In cycle 2, students who have scored in the very good category are 17 people.

3. Implementation of the giving task method has been able to improve students' learning achievements.

TABLE II

STUDENTS' ACHIEVEMENT IN CYCLE 2

\begin{tabular}{clc}
\hline No. & Name of Students & Score \\
\hline 1 & R1 & 89 \\
2 & R2 & 96 \\
3 & R3 & 86 \\
4 & R4 & 86 \\
5 & R5 & 84 \\
6 & R6 & 78 \\
7 & R7 & 84 \\
8 & R8 & 84 \\
9 & R9 & 91 \\
10 & R10 & 84 \\
11 & R11 & 84 \\
12 & R12 & 96 \\
13 & R13 & 81 \\
14 & R14 & 87 \\
15 & R15 & 78 \\
16 & R16 & 91 \\
17 & R17 & 81 \\
18 & R18 & 90 \\
19 & R19 & 75 \\
20 & R20 & 89 \\
21 & R21 & 78 \\
\hline & Total & $\mathbf{1 7 9 2}$ \\
& Average & $\mathbf{8 5 . 3 3 3 3 3 3 3 3}$ \\
& & $\mathbf{8 5 . 3 3}$ \\
\hline
\end{tabular}

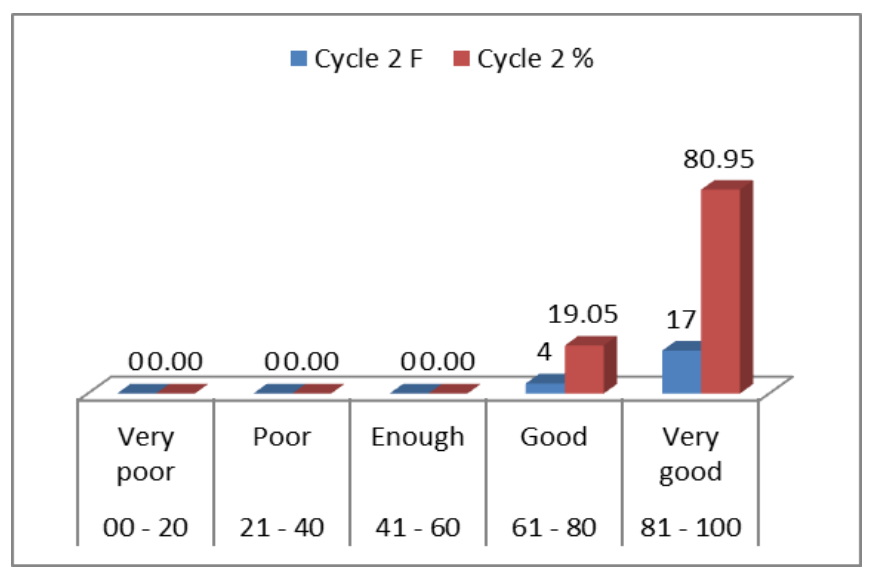

Fig. 2 Students' learning achievement in Cycle 2

The progress of students' learning achievements can be seen in Fig. 3. The average of students' learning achievement on each cycle can be seen in Fig.4.

This study was conducted to improve students' learning achievements on the letter of credit material. The means used to improve student learning outcomes is the method of giving tasks with subjective tests for each cycle. Regarding the view that the method of giving tasks is a method of learning that makes learners active, responsible, social interaction, critical thinking, and have high learning motivation, while the lecturer is also easy in teaching because students quickly perceive and understand the material provided. Then the method of giving tasks is believed as a method of learning that can improve students' learning achievements and understanding, and develop their mindset in the learning process.

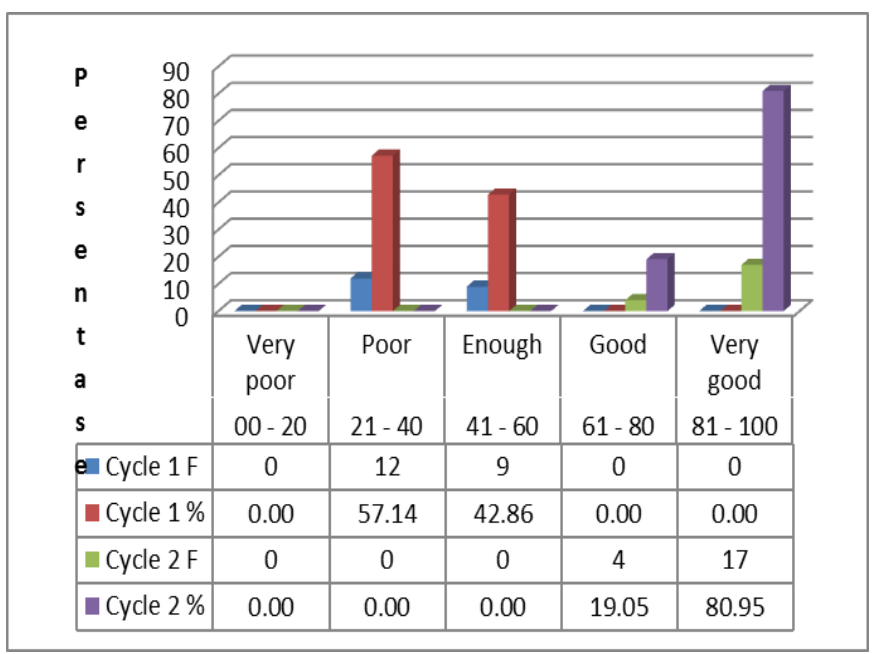

Fig. 3 The improvement of IB Students' learning achievements

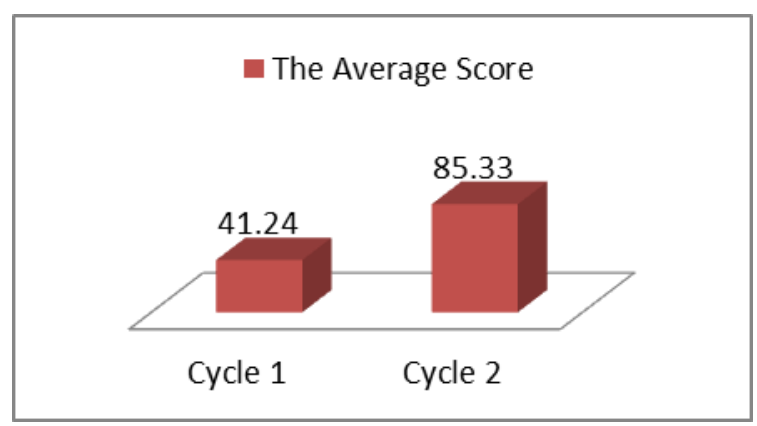

Fig. 4 The improvement of students' score

In Cycle 1, during the learning process, there are only some students who are active and interact in doing the tasks assigned to both individuals and groups. Some students look bored, saturated, drowsy, confused, and indifferent during the learning process, they rely on one group of friends in finding answers for the task or imitate the results of the task from their friend in another group who has the same task with him. When the lecture material inference process is done, the students tend to be indifferent. Nevertheless, teaching and learning activities run smoothly, but the liveliness and responsibility of students in learning are still less than satisfactory. Of course, their insights and knowledge did not increase, because of their low learning motivation. The result of the evaluation conducted by the lecturer at the end of learning to 21 students of level I.B Economic Education showed that the average of students' learning achievements in Cycle 1 is less satisfactory. 
In Cycle 2, students actively engage and interact in the work assigned. They do the task independently and discuss it with other group members who have the same task. They are also more active in presenting tasks, as well as expressing their ideas/opinions. Students' mindset develops well because their insights and knowledge grow, their learning motivation is high, their sense of responsibility for the task is high, and the learning atmosphere is conducive and fun. Nevertheless, some students are still indifferent during the learning process, they have not been motivated to study harder yet. The results of the evaluation conducted by the lecturer at the end of the learning at I.B class Economic Education showed that the average of students' learning achievements in Cycle 2 is satisfactory.

The learning process with the method of giving the task from 2 cycles that have been done has a satisfactory improvement. It happens because the students' motivations to study are high, which is according to Rowntree's statement (Anshori, Wagimin, \& Ninghardjanti, 2016). The students are active, interacting, confident, and responsible in performing the tasks assigned by the lecturer, both individual and group tasks. In the learning process, the mindset of students is growing well because their insights and knowledge increase, especially about the letter of credit.

In this method, all tasks given by lecturers are done well by students, both individual tasks, and group tasks. This is the following statement (Permatasari, Mulyani, \& Nurhayati, 2014). The work done by the students themselves is useful for themselves in understanding the results of the task so that when the lecturer explains the learning materials, the material can be easily comprehended and understood by the students, following opinions (Widhiantari, 2012).

The improvement of students' learning achievements is influenced by the success and effectiveness of the teaching and learning process that has been implemented. Factors that affect the success and effectiveness of this teaching-learning process, are the sense of responsibility and motivation that encourage the spirit of students to learn well, such as the opinion of Sudjana (Sitompul, 2018). Without a sense of responsibility and motivation to learn, then the readiness of students will not be created, so that students' learning achievements will not increase. Besides, the selection of the learning method also determines the success and effectiveness of teaching and learning activities in the classroom.

\section{CONCLUSIONS}

The classroom action research conducted at Campus 2 Unswagati Cirebon at I.B grade students about the application of the giving task method to improve students' learning achievements shows the expected results. Students' learning achievements have increased significantly. It can be seen from the average scores of students' learning achievements in Cycle 1 and Cycle 2, which can be summarized as follows:

1. Cycle 1 shows that 21 students as a sample of this research, it is known that the average learning achievement is 41.24 (enough).
2. Cycle 2 shows that 21 students as a sample of this research, it is known that the average learning achievement is 85.33 (very good). From the evaluation test results, it can be seen that there is an increase in students' learning achievement average.

The method of giving task can assist the students in understanding the concept of the letter of credit, it can be seen when the student can do the task independently, issuing opinion/idea, answer the questions given by the lecturer, and do the test well. In Cycle 1, the students' learning achievements are considered less, because some students look bored, saturated, drowsy, confused, and indifferent during the learning process, they rely on a group of friends in the task or imitate the results of the task from his friend in another group who has the same task with him, so that when the lecture material inference process done the students tend to be indifferent. Nevertheless, teaching and learning activities run smoothly, but the liveliness and responsibility of students in learning are still less than satisfactory. In Cycle 2, students actively engage and interact in the work assigned. They do the task independently and discuss it with other group members who have the same task. They are also more active in presenting tasks, as well as expressing their ideas/opinions. Students' mindsets develop well because their insights and knowledge grow, their learning motivation is high, their sense of responsibility for the task is high, and the learning atmosphere is conducive and fun.

\section{REFERENCES}

Anshori, M. Zaki Syaifudin., Wagimin, Ign., \& Ninghardjanti, Patni. (2016). Penerapan Model Pembelajaran Kooperatif Tipe Student Team Achievement Division (STAD) Untuk Meningkatkan Hasil Belajar Siswa pada Mata Pelajaran Mengelola Sistem Kearsipan Kelas XI Administrasi Perkantoran 1 SMK Negeri 4 Klaten Tahun Pelajaran 2014/2015. [Online]. Available: https://digilib.uns.ac.id/dokumen/detail/52051/Pene rapan-Model-Pembelajaran-Kooperatif-TipeStudent-Team-Achievement-Division-STADuntuk-Meningkatkan-Hasil-Belajar-Siswa-padaMata-Pelajaran-Mengelola-Sistem-KearsipanKelas-XI-Administrasi-Perkantoran-SMK-Negeri4-Klaten-Tahun-Pelajaran-20142015

Istiatutik. (2017). Penerapan Metode Problem Based Learning untuk Meningkatkan Hasil Belajar Pelajaran Ekonomi. Jurnal Pendidikan: Riset \& Konseptual, 1, 45-51.

Khumaidi. (2018). Peningkatan Aktivitas Belajar Ekonomi Dengan Menggunakan Model Pembelajaran Course Review Horay. [Online]. Available: https://ejournal.uksw.edu

Permatasari, Aprilia Intan., Mulyani, Bakti., \& Nurhayati, Nanik Dwi. (2014). Efektivitas Penggunaan Model Pembelajaran Joyful Learning Dengan Metode Pemberian Tugas Terhadap Prestasi Belajar Siswa Pada Materi Pokok Koloid Siswa Kelas XI IPA 
SMA Negeri 1 Simo Tahun Pelajaran 2012/2013. Jurnal Pendidikan Kimia (JPK), 3, 117-122.

Sagala, Syaiful. (2013). Konsep dan Makna Pembelajaran. Bandung: Alfabeta.

Sitompul, Horas. (2018). Peningkatan Aktivitas dan Hasil Belajar Ekonomi Melalui Model Pembelajaran Inquiri Pada Siswa Kelas XI IPS 1 SMA Negeri 1 Pinangsori Kabupaten Tapanuli Tengah Provinsi Sumatera Utara Tahun Pelajaran 2017/2018. Nusantara (Jurnal Ilmu Pengetahuan Sosial), 4, 1-6.

Sukardi. (2013). Metode Penelitian Pendidikan Tindakan Kelas Implementasi dan Pengembangannya. Jakarta: Bumi Aksara.
Suprijono, Agus. (2011). Cooperstive Learning Teori dan Aplikasi PAIKEM, Yogyakarta: Pustaka Belajar.

Suyadi. (2013). Panduan Penelitian Tindakan Kelas. Yogyakarta: Diva Press.

Widhiantari, Rahma. (2012). Efektivitas Metode Pemberian Tugas (Resitasi) Berbantuan Modul Pembelajaran Terhadap Hasil Belajar Siswa Kompetensi Dasar Uang dan Perbankan SMA N 1 Kota Mungkid Kabupaten Magelang. EEAJ (Economic Education Analysis Journal), 1, 1-6. 